\title{
Shallow hydrocarbon gas in the northern Jutland- Kattegat region, Denmark
}

\author{
NIELS OLUF JØRGENSEN, TROELS LAIER, BJØRN BUCHARDT AND TOMMY CEDERBERG.
}

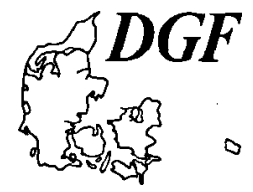

\begin{abstract}
Jørgensen, N. O., Laier, T., Buchardt, B. and Cederberg, T.: Shallow hydrocarbon gas in the northern Jutland-Kattegat region, Denmark, Bull. geol. Soc.. Denmark, Vol. 38, pp. 69-76, Copenhagen, April 25th, 1990. https://doi.org/10.37570/bgsd-1990-38-07

Carbon and hydrogen isotopic compositions and chemical analyses are reported for gas samples collected from 11 gas wells, two gas seeps and 8 water wells in Vendsyssel, northern Jutland, and the island of Læsø in Kattegat, Denmark. The chemical composition shows methane-rich gas, poor in heavy gaseous hydrocarbons with a $\mathrm{C}_{2+}$ concentration less than $0.01 \%$. The methane is relatively depleted with respect to the heavy isotopes, i.e. $\delta^{13} \mathrm{C}:-63.6 \%$ to $-89.2 \% \delta^{2} \mathrm{H}:-177 \%$ to $-2288 \%$. The data fall within the range which is generally considered to characterize microbial gas formed via $\mathrm{CO}_{2}$ reduction. There is no evidence of contribution of gas from thermogenic sources.

The gas is known from a large number of gas wells and water wells in Upper Pleistocene marine deposits and from submarine gas seeps in the Kattegat. The gas field has a NW toSE areal extent subparallel to the northem limit of the Danish sub-basin and the major fault-systems of the Fennoscandian border zone. This distribution coincides with the occurences of a tectonic depression in the pre-Quaternary surface which primarily is filled in with Eemian and Weichselian marine sediments. The gas most likely derives from degradation of organic material in the Upper Pleistocene marine sediments themselves and is subsequently trapped in restricted reservoirs of sand and gravel.
\end{abstract}

N. O. Jørgensen and B. Buchardt, Institute of Historical Geology and Palaeontology, University of Copenhagen, Øster Voldgade10, DK-1350, Denmark. T. Laier, Geological Survey of Denmark, Thoravej 8, DK-2400, Denmark. T. Cederberg, National Environmental Research Institute, Mørkhøj Bygade 26, Bygning H, DK-2860, Denmark. May 22th, 1989.

\section{Introduction}

Shallow hydrocarbon gas occurs in the northern Jutland-Kattegat area of Denmark. The gas is known from a large number of shallow gas wells, water wells and gas seeps from the soils in Vendsyssel, North Jutland, from submarine gas seeps an from an exploration well on the island of Læs $\varnothing$ in the Kattegat area (fig. 1). The gas was first encountered in 1865 and was later exploited as a local energy supply in the FrederikshavnStrandby area, especially during the Second World War. A total of approximately 20 million $\mathrm{m}^{3}$ of hydrocarbon gas was recovered with a maximum pressure of approximately 15 bars.

The gas is encountered in Late Quaternary interglacial or late glacial marine deposits which show a northwest-southeast areal extent subparallel to the Fennoscandian border zone (fig. 1) (Jessen, 1936; Dreyer Jørgensen, 1945; Fredericia \& Grambo-Rasmussen, 1989). Chemical analyses of the gas previously recorded from the on-land gas wells show methane with up to $3 \%$ of carbon dioxide and only traces of higher hydro- carbons (Astrup, 1940). A carbon-13 analysis, made by Gulf Oil in the sixties, revealed relatively negative $\delta^{13} \mathrm{C}$ values, i.e. $-63 \%$ PDB (unpublished data).

A carbon-14 dating performed on the methane of a gas samples taken in 1982 while testing a $46 \mathrm{~m}$ deep weel on the island of Læs $\emptyset$, gave an age of 33.000 years B.P. This probably represents a minimum age of the organic matter from which the gas was generated, since the gas may have been slightly contaminated due to a rather poor sampling technique (J. M. Hansen, pers. comm.).

The origin of the gas has periodically become a source of intensive debate and speculation. Recent studies of submarine gas seepages and methane-derived carbonates in the Kattegat area have caused new interest in the formation of the gas (Hansen, 1988; Jørgensen, 1989). The composition of the gas indicates a microbial origin from the Late Quaternary marine deposits themselves. However, the geological setting of the gas bearing strata is closely associated with the major fault-system in the Fennoscandian border zone 


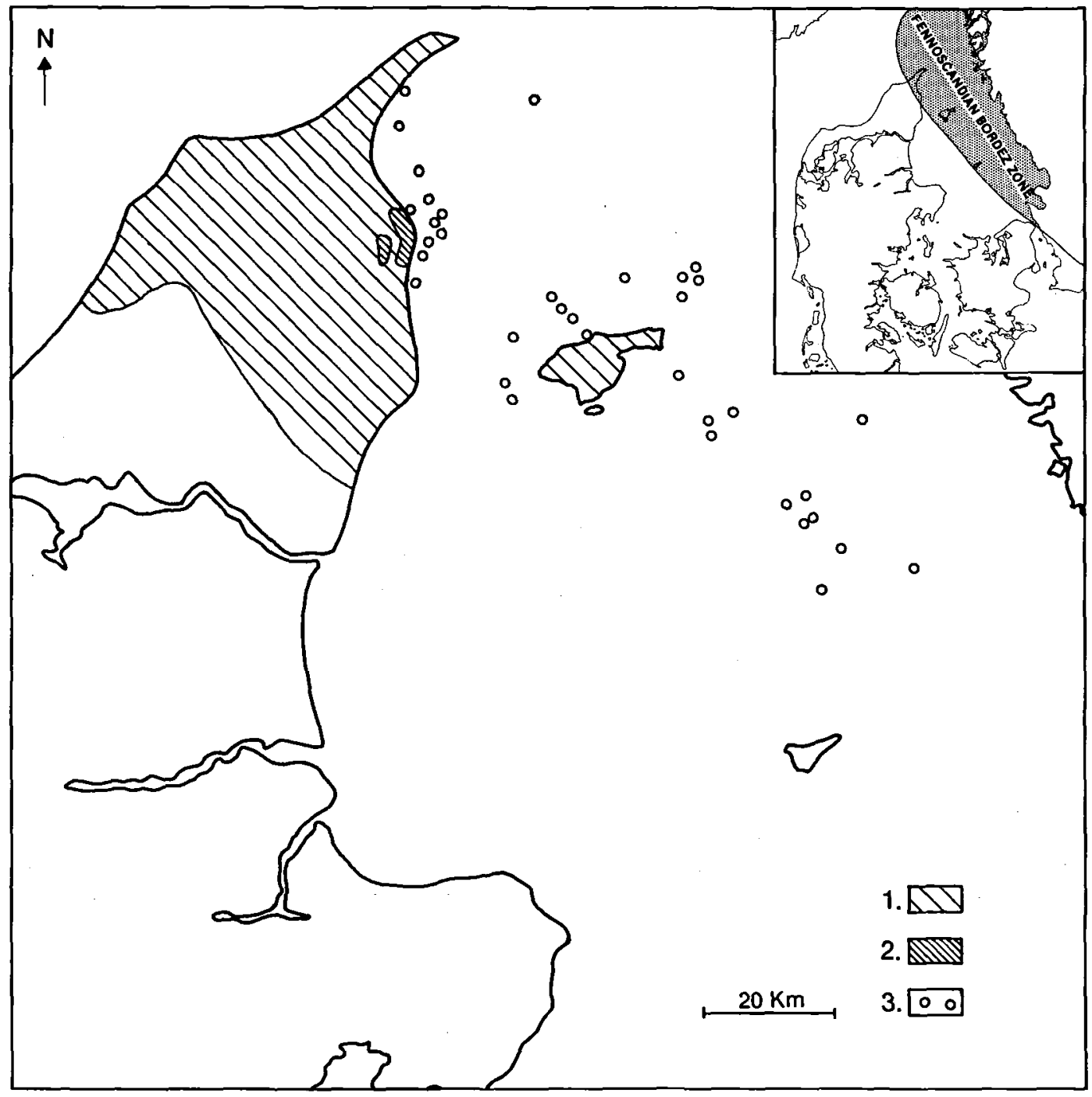

Fig. 1. The occurrences of Quaternary gas in Vendsyssel, northern Jutland, and the Kattegat area. 1. The area in which gas has been recorded from a large number of water wells, shallow gas wells and gas seeps. 2 . The commercial gas fields (now abandoned) in the Frederikshavn-Strandby area (see Sorgenfrei, 1952). 3. Occurrences of submarine gas seeps and methane-derived carbonates in the Kattegat area. The locations shown are on the basis of informations from fishermen and SCUBA divers and off-shore harbour constructions (Hansen, 1988; Jørgensen, 1976). The index map shows the position of the Fennoscandian border zone.

one cannot exclude mixing with deep pre-Quaternary thermogenic gas. It is the objective of this study to unravel the source of the gas on the basis of the chemical composition and the carbon and hydrogen isotopic signatures and discuss these data together with the results from previous investigations.

\section{Sampling methods and analytical techniques}

\section{Sampling}

Gas samples were taken from all accessible gas wells in the northern Jutland area. These wells were, however, concentrated in the Frederikshavn-Strandby area. In order to examine hydrocarbon gases over a large area, dissolved gases in 


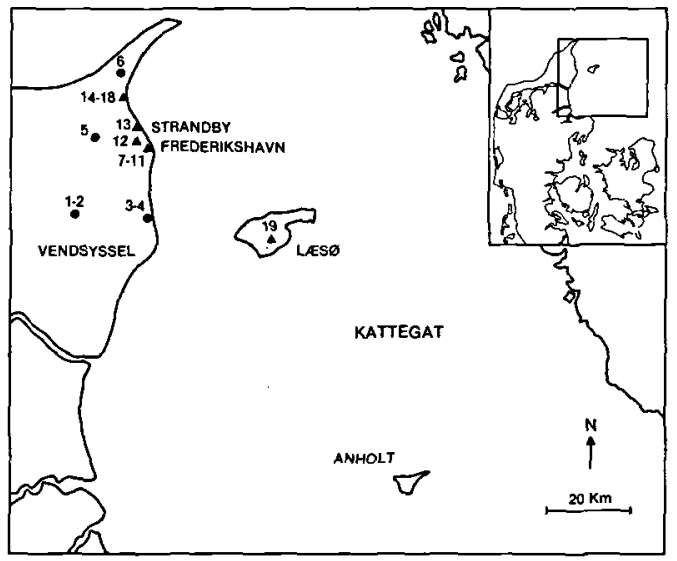

Fig. 2. The locations of water wells (infilled circles), gas wells and gas seeps (triangles) studied in the present paper. 1-2: Østervrå Waterwork; 3-4: Sæby, Ørnedal Waterwork; 5: Tolne Waterwork; 6: Bunken Waterwork; 7-11: Gas wells in Frederikshavn; 12: Gas well in Elling; 13: Gas well in Strandby; 14-18: Three gas wells and two gas seeps in Ålbæk; 19: Shallow exploration well in Byrum, Læsø.

the ground water were also sampled from a number of water supply wells (fig. 2).

Gas samples were mainly taken from the hose connected to a gas burner or from a valve on the well head. The exploration well on the island of Læsø started to produce gas the water table was lowered a few metres, so gas samples were also taken from this well (fig. 2).

Gas samples for analyses of the chemical composition of the gas and isotopic analysis of methane were collected and stored in evacuated $12 \mathrm{ml}$ glass tubes, venoject $\mathrm{R}$, made for blood tests. Gas samples for isotopic analyses of carbon dioxide were collected in $100 \mathrm{ml}$ stainless steel cylinders from a limited number of gas wells.

Water samples for analyses of dissolved hydrocarbons were sampled and stored in evacuated $12 \mathrm{ml}$ glass tubes, venoject $R$. The water was collected by a syringe at the well head, when fresh ground water was produced, and $6 \mathrm{ml}$ were injected as quickly as possible into the glass tube.

Water samples for stable isotopic analyses of dissolved methane were collected in $100 \mathrm{ml}$ stainless steel cylinders at well head pressure.

\section{Analyses}

Gas samples were analysed on a gaschromatograph equipped with a thermal conductivity de- tector (TCD). A molecular sieve 5A column was used to separate the gas components using temperature programming $100^{\circ} \mathrm{C}-250^{\circ} \mathrm{C}$, with a $\mathrm{He}$ carrier gas flow rate of $20 \mathrm{ml} / \mathrm{min}$.

Due to reequilibration most of the dissolved gases accumulated in the gas phase of the Venoject tubes containing the water samples. In a 1:1 gas to water ratio at $25^{\circ} \mathrm{C} 96 \%$ of the total methane will exist in the gas phase (McAuliffe, 1969). The gas phase of the water samples was analysed for hydrocarbon gases on a gaschromatograph equipped with a flame ionization detector (FID). Hydrocarbon contents were separated on a silica gel $70 / 80$ mesh column at $100^{\circ} \mathrm{C}$ with a He carrier gas flow rate of $20 \mathrm{ml} / \mathrm{min}$.

Larger quantities of gas are required for stable isotopic analyses compared to the gaschromatograph analyses. For the water samples all dissolved gas in the $100 \mathrm{ml}$ samples was used for stable isotopic analyses. The dissolved gases were first released by agitating the water with a magnetic stirrer in an evacuated glass bottle. The gas was then transferred to a molecular sieve $5 \mathrm{~A}$ column using a $\mathrm{He}$ carrier gas flow of $40 \mathrm{ml} / \mathrm{min}$. The column was cooled in liquid nitrogen to collect the gas on top of the column. Methane was then separated from the other gases by heating the column to room temperature, and oxidized by $\mathrm{CuO}$ at $900^{\circ} \mathrm{C}$. The involved $\mathrm{CO}_{2}$ and $\mathrm{H}_{2} \mathrm{O}$ were separated and purified cryogenically. Stable isotopic analyses were performed on the $\mathrm{CO}_{2}$ and on the $\mathrm{H}_{2}$ resulting from the reduction of the $\mathrm{H}_{2} \mathrm{O}$ by $\mathrm{Zn}$ at $700^{\circ} \mathrm{C}$ in a Finnigan MAT 250 triple collector mass spectrometer. Gas samples were analysed for stable isotopic composition by the same procedure by injecting 0.5 to $1 \mathrm{ml}$ of the gas on the molecular sieve $5 \mathrm{~A}$ column cooled in liquid nitrogen.

The carbon and hydrogen isotopic ratios were expressed as per mil deviation from the international standards PDB and SMOW respectively. Standard deviation for stable carbon isotopic ratios is \pm 0.2 per mil and for deuterium/hydrogen \pm 3 per mil.

Stable isotopic analyses on the carbon dioxide associated with the methane in the gas samples were performed on the $100 \mathrm{ml}$ gas samples. The steel cylinder was connected to an evacuated system, the valves were opened, and the gas was passed through a liquid nitrogen cooled trap using $\mathrm{He}$ as a carrier gas. The trapped $\mathrm{CO}_{2}$ was 
Table 1. Results of analyses of samples from gas wells.

\begin{tabular}{|c|c|c|c|c|c|c|c|c|c|}
\hline $\begin{array}{l}\text { Sample } \\
\text { No. }\end{array}$ & Locality & $\begin{array}{l}\text { Depth } \\
\text { (m) }\end{array}$ & $\begin{array}{l}\mathrm{CH}_{4} \\
(\%)\end{array}$ & $\begin{array}{l}\mathrm{CO}_{2} \\
(\%)\end{array}$ & $\begin{array}{c}\mathrm{N}_{2} \\
(\%)\end{array}$ & $\begin{array}{c}\mathrm{O}_{2}+\mathrm{Ar} \\
(\%)\end{array}$ & $\begin{array}{c}\delta^{13} \mathrm{C}_{\mathrm{CH}_{4}} \\
(\%)\end{array}$ & $\begin{array}{c}\delta^{2} \mathbf{H}_{\mathrm{CH}_{4}} \\
(\%)\end{array}$ & $\begin{array}{c}\delta^{13} \mathrm{C}_{\mathrm{CO}_{2}} \\
(\%)\end{array}$ \\
\hline \multicolumn{10}{|c|}{ Frederikshavn City: } \\
\hline 7 & Hjørringvej 41 & 117 & 88.0 & 2.2 & 7.6 & 2.2 & -63.6 & -187 & 6.3 \\
\hline 9 & Skippergade 48 & & 94.8 & 1.8 & 2.6 & 0.8 & -64.8 & -180 & 1.0 \\
\hline 11 & Danmarksgade 41 & & 42.0 & 0.7 & 44.7 & 12.6 & -64.4 & -172 & \\
\hline \multicolumn{10}{|c|}{ Frederikshavn North: } \\
\hline 8 & Flade Engvej 60 & 80 & 92.7 & 1.5 & 4.5 & 1.3 & -72.2 & -189 & -3.3 \\
\hline 10 & Skagensvej 106 & 84 & 94.3 & 0.8 & 3.9 & 1.0 & -72.0 & -197 & \\
\hline \multicolumn{10}{|l|}{ Elling: } \\
\hline 12 & Mariendalsvej 37 & & 94.5 & 0.9 & 3.6 & 1.0 & -67.8 & -204 & \\
\hline \multicolumn{10}{|c|}{ Strandby: } \\
\hline 13 & Nymarksvej 8 & & 92.6 & 1.0 & 5.0 & 1.4 & -65.5 & -197 & \\
\hline \multicolumn{10}{|c|}{ Ålbak: } \\
\hline 14 & Cafeteria, Skagensvej & surf. & 86.8 & 0.4 & 10.0 & 2.8 & -68.8 & -177 & \\
\hline 15 & Sdr. Havnevej 46 & surf. & 88.3 & 0.5 & 8.7 & 2.5 & -73.6 & -205 & \\
\hline 16 & Fugleholmvej 6 & & 95.5 & 0.5 & 3.1 & 0.9 & -74.1 & -191 & -8.7 \\
\hline 17 & Ndr. Strandvej $12 \mathrm{~A}$ & & 89.8 & 0.4 & 7.6 & 2.2 & -69.6 & -201 & \\
\hline 18 & Samsøvej 8 & & 91.0 & 0.6 & 6.6 & 1.8 & -74.3 & -185 & \\
\hline \multicolumn{10}{|l|}{ Læsø: } \\
\hline 19 & Kromarksvej 6 & 46 & 88.1 & 0.3 & 9.3 & 2.3 & -89.2 & -192 & -15.3 \\
\hline
\end{tabular}

purified cryogenically and analysed with respect to stable carbon isotopic ratio.

\section{Results and discussions}

Most commercial natural gases are believed to be of thermogenic origin. However, it has been estimated that more than $20 \%$ of all known resources of natural gas are of biogenic origin (Rice \& Claypool, 1981), and an increasing number of natural gas occurrences are shown to consist of mixtures of microbial and thermogenic gases (Rice \& Claypool, 1981; Dudley et al., 1988; Jenden et al., 1988).

Several recent studies have demonstrated a large variability in the isotopic compositions of methane (e.g. Jenden \& Kaplan, 1986). These variations have been ascribed to isotopic differ- ences between thermogenic and microbial gases, to the different pathways involved in the microbial degradation of organic matter and to factors such as source of material and environment of formation.

Carbon and hydrogen isotopic studies of methane have therefore proved to be an important tool in determining the origin of methane from different sources.

Chemical and isotopic compositions of the gases Gas chromatographic analyses of gas samples showed up to $94.8 \%$ methane and up to $2.2 \%$ of carbon dioxide (table 1). The contents of higher hydrocarbons were below the detection limit, i.e. $0.01 \%$. The ratios of nitrogen to oxygen in the gas samples are close to the atmospheric ratio and the presence of these two gases most likely is

Table 2. Results of analyses of samples from water wells.

\begin{tabular}{llcccccc}
\hline $\begin{array}{l}\text { Sample } \\
\text { No. }\end{array}$ & Locality & $\begin{array}{c}\text { DGU well } \\
\text { file No. }\end{array}$ & $\begin{array}{c}\text { Depth } \\
(\mathrm{m})\end{array}$ & $\begin{array}{c}\mathrm{CH}_{4} \\
(\mathrm{mg} /)\end{array}$ & $\begin{array}{c}\mathrm{C}_{2} \mathrm{H}_{6} \\
(\mathrm{mg} / \mathrm{l})\end{array}$ & $\begin{array}{c}\delta^{13} \mathrm{C}_{\mathrm{CH}_{4}} \\
(\%)\end{array}$ & $\begin{array}{c}\delta^{2} \mathrm{C}_{\mathrm{CH}_{4}} \\
(\%)\end{array}$ \\
\hline 1 & Østerviå & 10.452 & 20 & 0.4 & 0.001 & & \\
2 & $\emptyset$ stervrå & 10.429 & 33 & 3.2 & 0.000 & -66.8 & -133 \\
3 & Sxby & 11.545 & 94 & 6.2 & 0.002 & -79.5 & -221 \\
4 & Sxby & 11.682 & 84 & 2.9 & 0.001 & -75.5 & -196 \\
5 & Tolne & 6.316 & 60 & 7.3 & 0.000 & -76.1 & -228 \\
6 & Bunken & & 18 & 4.7 & 0.000 & -70.6 & -202 \\
\hline
\end{tabular}




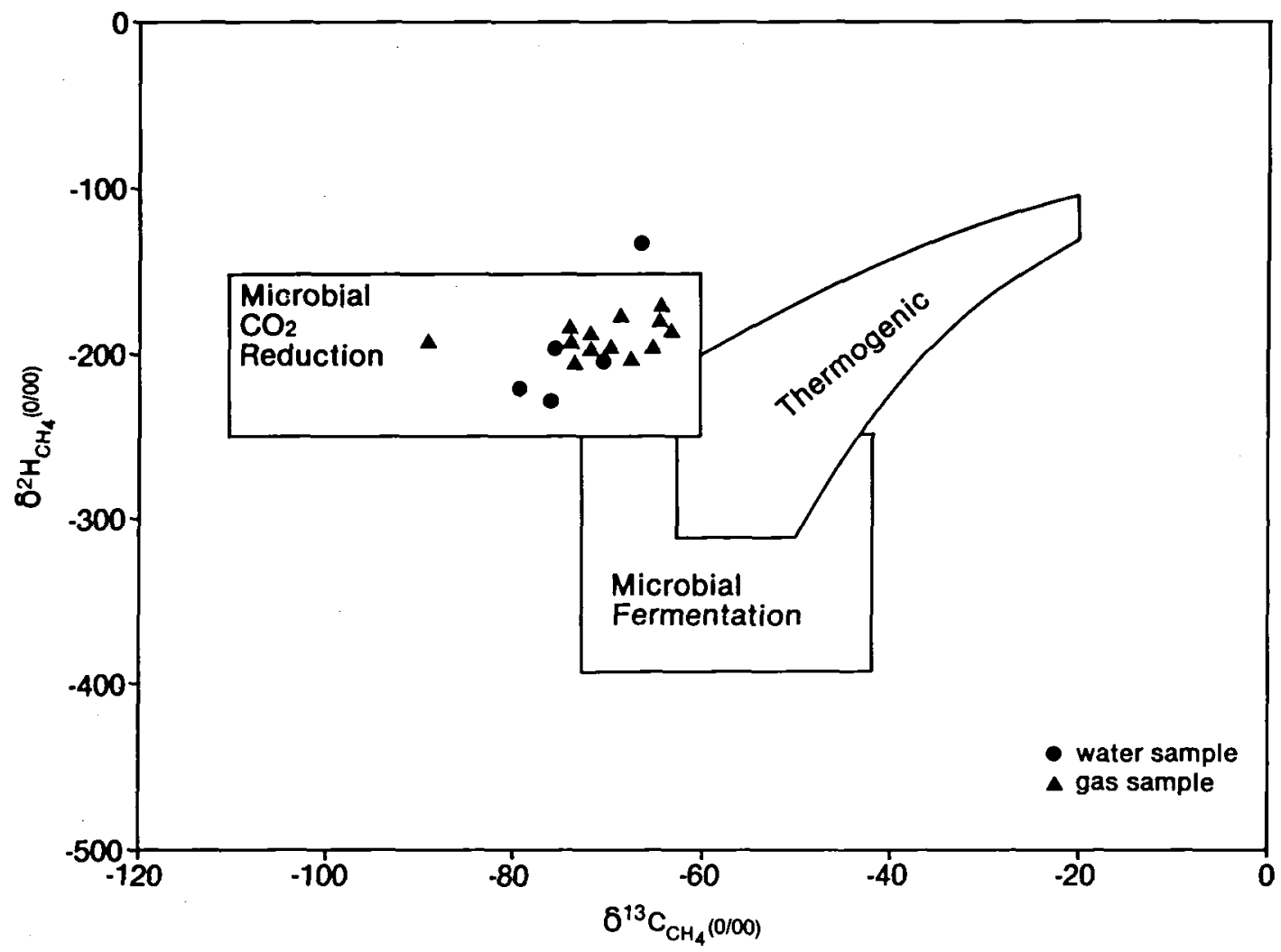

Fig. 3. Carbon and hydrogen isotopic compositions of methane from Vendsyssel and Lxsø and their relationship to the genetic classification scheme of Schoell (1988).

due to atmospheric contamination. Atmospheric contamination is practically unavoidable with the simple sampling technique applied. However, the sampling technique have been found adequate for the stable isotopic analyses, which was the primary goal of this study.

The chemical composition of the gases studied is in good agreement with analyses of gas previously recorded from the Frederikshavn-Strandby area (Astrup, 1940). However, a single gas sample from Strandby analysed by Gulf Oil in 1937 yielded a significant amount of $\mathrm{C}_{2} \mathrm{H}_{6}$ (Astrup, 1940; Sorgenfrei, 1952), but the occurrences of heavy gaseous hydrocarbons have never been confirmed.

The methane from gas wells and water wells is relatively depleted in both the heavy carbon and the heavy hydrogen isotope (tables 1,2). Most $\delta^{13} \mathrm{C}_{\mathrm{CH} 4}$ values range from $-64 \%$ o to $-74 \%$. However, the methane collected from the exploration well at the island of Læs $\varnothing$ shows $\delta^{13} \mathrm{C}_{\mathrm{CH} 4}$ values as negative as $-89.2 \%$ (table 1 , fig. 3 ).
The chemical composition and carbon isotopic signature suggest a gas of microbial origin (Schoell, 1980 and 1983).

The hydrogen isotopic compositions show $\delta^{2} \mathrm{H}_{\mathrm{CH} 4}$ values in the range of $-172 \%$ o to $-228 \%$. A single sample from a water well shows a less deuterium-depleted methane, $\delta^{2} \mathrm{H}:-133 \%$ and a corresponding $\delta^{13} \mathrm{C}$ value of $-66.8 \%$ (table 2 , fig. 3). However, this composition most likely is the result of subsequent isotopic fractionation caused by methane-oxidizing bacteria (Coleman et al., 1981).

Fig. 3 shows the carbon and hydrogen isotopic compositions of methane from both gas wells and water wells plotted on the genetic classification scheme proposed by Schoell (1988). The data fall within the range which is generally considered to characterize microbial methane that form by $\mathrm{CO}_{2}$ reduction (Schoell, 1988).

Stable carbon isotopic analyses of the $\mathrm{CO}_{2}$ in a few gas wells show $\delta^{13} \mathrm{C}$ values which vary from $-15.3 \%$ to $+6.3 \%$ (table 1 ). The stable carbon 
isotopic value of microbial methane and the associated carbon dioxide have been shown to be dependent on the mechanism of methane formation (Whiticar et al., 1986; Whiticar and Faber, 1986). The relationship between the present pair of carbon-13 data for methane and carbon dioxide falls within the field of the $\mathrm{CO}_{2}$ reduction pathway found empirically by these authors. However, it has to be noted that the methane does not neccesarily derives exclusively from the associated $\mathrm{CO}_{2}$ since contribution of $\mathrm{CO}_{2}$ from other sources may have taken place.

\section{The geological setting of the gas bearing strata}

Gas has been recorded in approximately 500 registered shallow gas wells and water wells in Vendsyssel, northern Jutland, since the middle of the last century (Fredericia \& Grambo-Rasmussen, 1989). The gas is generally encountered in horizons of sand and gravel. But the lithology in most of these wells is known only in broad outline and the stratigraphy is practically unknown. However, further studies of available data from the commercial gas fields in the FrederikshavnStrandby area revealed that the gas was encountered in two major horizons (from $-180 \mathrm{~m}$ to $-160 \mathrm{~m}$ and from $-120 \mathrm{~m}$ to $-70 \mathrm{~m}$ below sea level) in Eemian to Early Weichselian marine sandy deposits carrying saline formation water (Astrup, 1940; Dreyer Jørgensen, 1945; Sorgenfrei, 1952; Fredericia \& Grambo-Rasmussen, 1989). Fredericia \& Grambo-Rasmussen (1989) have estimated that the maximum gas pressure measured in the Frederikshavn-Strandby area (up to 15 bars) correspond to the hydrostatic pressure at the depth of Eemian-Early Weichselian marine deposits in accordance with the assumption that these deposits are the source of the methane gas. The formation of gas deposits of shallower depth with gas presures slightly above the hydrostatic pressure are caused by certain hydrological conditions where the concentrations of dissolved microbial gases exceed the saturation limit and thus form a gas phase which subsequently is trapped in restricted reservoirs of sand and gravel.

The exploration well on the island of Læs $\varnothing$ showed gas at a depth of $46 \mathrm{~m}$ in Early Weichselian marine deposits also carrying saline forma- tion water (Bahnson et al., 1986). In contrast, the methane gas in the village of Ålbæk is observed at a relatively shallow depth, generally less than $20 \mathrm{~m}$, and as gas seeps. Furthermore, extensive submarine gas seeps are observed just off-shore the village of $\AA$ lbæk. The fact that all on-shore gas occurrences as well as the submarine gas seeps in the Ålbak area fall on an almost straight line NW-SE indicates the presence of a conduite created by neo-tectonic activity.

Submarine gas seeps are a relatively common phenomenon in the Kattegas area. The gas is generally observed as gas bubbles at sea (Jessen, 1936) and several occurrences of gas discharges from the sea bottom have been recorded by SCUBA divers in the last decade (Hansen, 1988). Furthermore, shallow seismic surveys carried out in the areas in between Frederikshavn and Læs $\emptyset$ (Larsen et al., 1986) and in Skagerak and northern Kattegat (van Weering, 1982) revealed extensive occurrences of gas in the Late Quaternary sedimentary sequence.

The submarine gas seeps are associated with carbonate cementation of the uppermost sedimentary sequence. Generally, the carbonate cemented sandstones occur as individual slabs or more widely distributed thin pavements (Jørgensen, 1976). Occasionally, the lithified sandstones take the form of large, vertical pillar and mushroom-like bodies, which subsequently have been exposed as spectacular sandstone formations on the sea floor by large scale submarine erosion yielding a hard substrate for a rich epifauna and -flora (Hansen, 1988; Jørgensen, 1976 and 1989). The carbonate cements consist of aragonite, high- $\mathrm{Mg}$ calcite and dolomite. The carbonates are remarkably depleted in ${ }^{13} \mathrm{C}$, i.e. $\delta^{13} \mathrm{C}$ values in the range of $-45 \%$ o to $-55 \%$, and are therefore interpreted as being the result of methane oxidation (Jørgensen, 1976 and 1989). However, the relatively heavy carbon isotopic composition of the carbonates in comparison to the gas is most likely the results of subsequent isotopic fractionation caused by methane-oxidizing bacteria and/or contribution from the inorganic bicarbonate pool in the sea water.

The gas seeps and the methane-derived carbonates are occasionally accompanied by subordinate occurrences of authigenic gypsum and it is noteworthy that the isotopic signature of the sulphur from this gypsum indicates an origin from 
formation water in shallow gas reservoirs (Jørgensen, 1980).

It is interesting to note that the petrography and geochemistry of the carbonate cements in these sandstone formations are remarkably similar to the high-Mg calcite/aragonite cemented sandstones found in association with gas sepages and pockmarks in the North Sea oil fields and elsewhere described by Hovland \& Judd (1988).

The gas wells and the gas bearing water wells at Vendsyssel and the submarine gas seeps and methane-derived carbonates show an areal distribution which largely coincides with the general structural outline in the northern part of the Danish sub-basin. The distribution of Quaternary marine deposits is apparently governed by the Fennoscandian border zone and follows a faultbounded zone extending from Vendsyssel in the NW to Kategat and the $\emptyset$ resund region in the SE (Baartman \& Christensen, 1975; Liboriussen et al., 1987). Seismic investigations in the Vendsyssel-Kattegat area have revealed a NW-SE depression in the basal Quaternary, the 'Kattegat Basin', caused by the pre-Quaternary structural framework (Lykke-Andersen, 1987). Foraminiferal biostratigraphical studies of wells in Vendsyssel and from the islands of Læs $\varnothing$ and Anholt indicate that this depression was filled in mainly with Late Quaternary marine sediments (Bahnson et al., 1974; Knudsen \& Lykke-Andersen, 1982; Knudsen, 1984, 1985 and 1987; Lykke-Andersen, 1971 and 1987). The centre of the subsidence of this basin apparently shifted from SW in the pre-Eemian to the $\mathrm{NE}$ in the Eemian and Weichselian (Lykke-Andersen \& Knudsen, 1989). Thus, the Eemian and the Weichselian marine deposits obtain their maximum thickness to the northeast which largely coincides with the areal distribution of on-land gas occurrences and submarine gas seeps.

The geological setting and the chemical composition and isotopic signatures of the gas suggest that the gas was most likely generated by degradation of organic matter within the Upper Pleistocene marine sediments themselves. Some admixture of microbial terrestrial gas cannot be excluded to have taken place from intercalations of organic rich freshwater deposits. However, there is no evidence of any contribution from deep pre-Quaternary thermogenic gas based on the chemical and isotopic compositions of the gas.

\section{Conclusions}

Hydrocarbon gas in Late Quaternary marine sediments from the Vendsyssel-Kattegat area consists almost entirely of methane $\left(C_{2+}<0.01 \%\right)$ and is relatively depleted in ${ }^{13} \mathrm{C}$ with $\delta^{13} \mathrm{C}$ values in the range of $-63.6 \%$ to $-89.2 \%$. It is believed that gas with this composition characterizes only microbial gas. The hydrogen isotopic composition shows $\delta^{2} \mathrm{H}$ values in the range from $-172 \%$ to $-228 \%$. The carbon and hydrogen isotopic compositions indicate that the methane is formed primarily by $\mathrm{CO}_{2}$ reduction. There is no evidence of a contribution of gas from thermogenic sources.

The gas is known from a large number of gas wells and water wells in Vendsyssel and from submarine gas seeps in the Kattegat area. The gas bearing strata have a NW-SE extent subparallel to the Fennoscandian border zone in a tectonic depression in the pre-Quaternary surface which primarily is filled in with Eemian and Early Weichselian marine sediments. The gas was most likely generated by degradation of organic material within the marine sediments themselves and was subsequently trapped in restricted reservoirs of sand and gravel.

Acknowledgements. This work was carried out as a part of a larger project on surface geochemical exploration for hydrocarbons with financial support from the Danish Energy Agency (Grant No. EFP-1313/85-1). The authors are indebted to the owners of private gas wells and municipal waterworks from which gas and water samples have been collected. Jens Morten Hansen kindly offered accommodation and assistance in the field work on the island of Lasø. The mass spectrometer facility is funded by the Danish Natural Research council (S.N.F., grans no. 11-9372).

\section{Dansk sammendrag}

Naturgas forekommer $i$ begrænset omfang $i$ et stort antal boringer $i$ marine kvartære aflejringer $i$ Vendsyssel og som mindre gasudslip på havbunden i Kattegat. De største forekomster af gas er registreret i Frederikshavn-Strandby området, hvor de blev kommercielt udnyttet $i$ årene omkring 2 . Verdenskrig. Endnu i dag udnyttes gassen lokalt af enkelte lodsejere i området. Gassen bestảr næsten udelukkende af methan. De tungere kulbrinter udgør mindre end $0.01 \%$. Carbon og hydrogen isotopanalyser viser at gassen er relativ fattig på de tungere isotoper med $\delta^{13} \mathrm{C}$ værdier fra $-63.6 \%$ til $-89.2 \%$ PDB og $\delta^{2} \mathrm{H}$ vardier fra $-177 \%$ til $-228 \%$ SMOW. Denne isotopsammensætning er karakteristisk for mikrobiel methan, som er dannet via $\mathrm{CO}_{2}$ reduction. De geokemiske analyser giver således ingen evidens for en dybere, præ-Kvartær termogen oprindelse af de foreliggende gasforekomster.

Gasområdet i Vendsyssel og Kattegat har en NW-S $\emptyset$ 'lig udstrækning langs den Fennoskandiske randzone, sammenfal- 
dende med en tektonisk betinget depression i den præ-kvartære overflade, der hovedsageligt er fyldt op med marine sedimenter fra Eem og tidlig Weichsel. Det formodes, at gassen stamer fra mikrobiel nedbrydning af det organisk materiale i disse marine sedimenter og den siden er akkumuleret $i$ begrænsede sand- og grusreservoirer i den kvartære lagserie.

\section{References}

Astrup, J., 1940: Vendsyssel gas investigation. Danish American Prospecting Co., Report No. 91, 58pp.

Bartman, J. C. and Christensen, O. B.,, 1975: Contributions to the interpretation of the Fennoscandian border zone. Danmarks Geologiske Undersøgelse II. (102), 47 pp.

Bahnson, H., Petersen, K.S., Konradi, P.B. and Knudsen, K. L., 1974: Stratigraphy of Quaternary deposits in the Skærumhede II boring: Lithology, molluses and foraminifera. Danmarks Geologiske Undersøgelse, Årbog 1973, $27-62$.

Bahnson, H., Knudsen, K. L. and Hansen, J. M., 1986. Bidrag til Læsøs geologi. Lithologi, Biostratigrafi og Geofysik. Danmarks Geologiske Unders $\varnothing$ gelse, serie D nr. 6, 72pp.

Coleman, D. D., Risatti, J. b. and Schoell, M., 1981: Fractionation of carbon and hydrogen isotypes by methane-oxidizing bacteria. Geochim. Cosmochim. Acta 45, 10331037.

Dreyer Jørgensen, K., 1945: Frederikshavn-Strandby Gasområdets Geologi. Naturens Verden 29, 11-32.

Dudley, D. R., Threlkeld, C. N., and Vuletich, A. K., 1988: Character, origin and occurrence of natural gases in the Anadarko Basin, Southwest Kansas, Western Oklahoma and Texas Panhandle, U.S.A. Chemical Geology, 71, 149 157.

Fredericia, J. and Grambo-Rasmussen, A., 1989: Kortlcegning af kvartare gasfund $i$ Vendsyssel. Danm. geol. Unders., Intern rapport, fase 1-3, $15 \mathrm{pp}, 126 \mathrm{pp}, 13 \mathrm{pp}$. In prep.

Hansen, J. M., 1988: Koraller $i$ Kattegat. Kortlægning fase 1. Ministry of the Environment. The National Forest and Nature Agency, 1988. Internal rap., 11 pp.

Hovland, M. and Judd, A. G., 1988: Seabed Pockmarks and Seapages. Impact on Geology, Biology and the Marine Environment. Graham and Trotman, London, 1988. pp. 283.

Jenden, P. D. and Kaplan, I. R., 1986: Comparison of microbial gases from the Middle America Trench and Scripps Submarine Canyon; implication for the origin of natural gas. Appl. Geochem. 1, 631-646.

Jenden, P. D., Newell, K. D., Kaplan, I. R. and Watney, W. L., 1988: Composition and stable-isotope geochemistry of natural gases from Kansas, Midcontinent, U.S.A. Chemical Geology 71, 117-147.

Jessen, A., 1939: Vendsyssels Geologi. Danmarks Geologiske Unders $\phi$ gelse V. (2), 195pp.

Jørgensen, N.O., 1976: Recent high magnesian calcite/aragonite cementation of beach and submarine sediments from Denmark. Journ. Sed. Petrology 46, 940-952.

Jørgensen, N. O., 1980: Gypsum formation in Recent subma- rine sediments from Denmark. Chemical Geology 28, 349353.

Jørgensen, N. O., 1989: Holocene methane-derived dolomite cemented sandstone pillars from Kattegat, Denmark. $\mathrm{Ma}$ rine Geology 88, 71-81.

Knudsen, K. L., 1984: Foraminiferal stratigraphy in a marine Eemian-Weichselian sequence at Apholm, North Jutland. Bull. geol. Soc. Denmark 32, 169-180.

Knudsen, K. L., 1985: Correlation of Saalian, Eemian and Weichselian foraminiferal zones in North Jutland. Bull. geol. Soc. Denmark 33, 325-339.

Knudsen, K. L., 1987: elsterian-Holsteinian foraminiferal stratigraphy in North Jutland and Kattegat areas, Denmark. Boreas 16, 359-368.

Knudse, K. L. and Lykke-Andersen, A. L., 1982: Foraminifera in Late Saalian, Eemian, Early and Middle Weichselian of the Skærumhede I boring. Bull. geol. Soc. Denmark 30, 97-109.

Larsen, G., Baumann, J. and Bjørn, O., 1986: Kvartærgeologiske forhold under havbunden i Læs $\varnothing$ rende. Dansk $G e$ ologisk Forening, Årsskrift for 1985, 39-46.

Liboriussen, J., Ashton, P., and Tygesen, T., 1987: The tectonic evolution of the Fennoscandian Border Zone in Denmark. Tectonophysics 137, 21-29.

Lykke-Andersen, A.-L-. 1971: Foraminifera from the Older Yoldia Clay in Hirtshals. Bull. geol. Soc. Denmark 21, 159-184.

Lykke-Andersen, A.-L., 1987: A Late Saalian, Eemian and Weichselian marine sequence at Nørre Lyngby, Vendsyssel, Denmark. Boreas 16, 345-357.

Lykke-Andersen, A.-L. and Knudsen, K. L., 1989: Saalian, Eemian and Weichselian in the Vendsyssel-Kattegat Region, Denmark. STRIAE (in press).

Lykke-Andersen, H., 1987: Thickness of Quaternary deposits and their relation to the pre-Quaternary in the Fennoscandian border zone in Kattegat and Vendsyssel. Boreas 16, 369-371.

McAuliffe, C., 1969: Determination of dissolved hydrocarbons in subsurface brines. Chem. Geol. 4, 225-233.

Rice, D. D. and Claypool, G. E., 1981: Generation, accumulation, and resource potential of biogenic gas. Am. Assoc. Pet. Geol. Bull., 65, 5-25.

Schoell, M., 1983: Genetic characterization of natural gases. Am. Assoc. Pet. Geol. Bull., 67, 2225-2238.

Schoell, M., 1988: Multiple origins of methane in the earth, Chemical Geology 71. 1-10.

Sorgenfrei, Th., 1952: Natural gas in Denmark - Plans for - further exploration. Danish American Prospecting Co., Report No. 73, 3pp.

van Weering, T.C. E., 1982: Shallow seismic and acustic reflection profiles from the Skagerak: implications for Recent sedimentation. Proc. KNAW, Ser. B, 85, 129-154.

Whiticar, M.J. and Faber, E., 1986: Methane oxidation in sediment and water column environments - Isotope evidence. Org. Geochem., 10, 759-768.

Whiticar, M. J., Faber, E. F., and Schoell, M., 1986: Biogenic methane formation in marine and freshwater environments: $\mathrm{CO}_{2}$ reduction vs. acetate fermentation - Isotope evidence. Geocheim. Cosmochim. Acta 50, 693-709. 